\title{
Wpływ globalizacji i integracji w ramach MERCOSUR na wymianę handlową produktów przemysłu samochodowego Brazylii w latach 1990-2006
}

Rozwój przemysłu motoryzacyjnego w Brazylii nawiązuje do ogólnego wzorca industrializacji Ameryki Łacińskiej, w którym wyróżnia się trzy główne fazy. Z początkiem lat 90. $\mathrm{XX}$ w. rozpoczęła się trzecia $\mathrm{z}$ nich, wiążąca się $\mathrm{z}$ globalnym dostosowaniem się tego sektora do wyzwań wynikających z wprowadzenia nowych modeli produkcji przez azjatyckie koncerny. Fazę tę cechowała selektywna restrukturyzacja przemysłu motoryzacyjnego w niektórych państwach regionu, co miało umożliwić spełnienie rosnących wymagań na rynkach lokalnych oraz przeciwdziałać konkurencji na rynkach międzynarodowych. Była ona konieczna w obliczu likwidacji bądź ograniczeń pomocy rządowej i różnego rodzaju subsydiów wspierających eksport. W Brazylii restrukturyzacja polegała na gruntownej przebudowie istniejących oraz powstaniu wielu nowych, bardzo nowoczesnych zakładów, będących w stanie sprostać światowej konkurencji. Proces modernizacji tego sektora wymusiła także zmiana polityki gospodarczej. Odejście z początkiem lat 90 . XX w. od strategii rozwoju przemysłu poprzez substytucję importu i postępująca liberalizacja wymiany handlowej wymusiła na działających w tym kraju filiach międzynarodowych koncernów podjęcie działań restrukturyzacyjnych i modernizacyjnych. Dodatkową zachętą do pozostania na tym rynku lub do pojawienia się na nim - w przypadku nieobecnych wcześniej koncernów - były rozwijające się w tym samym czasie procesy regionalnej integracji gospodarczej w ramach MERCOSUR (Foreign Investment in Latin America and the Caribbean 1998; Foreign Investment in Latin America and the Caribbean 2003; Humphrey 2003).

Postępujący proces globalizacji przyspieszył liberalizację wymiany handlowej oraz swobodny przepływ kapitałów między państwami rozwijającymi się a rozwiniętymi. Wpłynął również na zmianę zachowań międzynarodowych koncernów samochodowych, które z coraz większym zainteresowaniem zaczęły spoglądać na kraje zaliczane do tzw. „wschodzących rynków”. W przeciwieństwie do nasyconych samochodami i cechujących się silną konkurencją rynków państw rozwiniętych, „wschodzące rynki” Ameryki Łacińskiej, Azji czy Europy Środkowo-Wschodniej jawiły się jako chłonne i mniej wymagające. Gwałtowny wzrost produkcji i sprzedaży samochodów odnotowany w tej grupie państw w pierwszej połowie lat 90. wywołał również falę inwestycji międzynarodowych koncernów. W Argentynie i Brazylii wartość sprzedaży samochodów w latach 1990-1997 wzrosła o 191,7\%, podczas gdy na rynku obejmującym Stany Zjednoczone i Kanadę zanotowano wzrost o 18,9\% zaś w Europie Zachodniej i Japonii spadek wartości sprzedaży odpowiednio o 3,0\% i 11,3\% (Humphrey 2003, s. 128; Laplane, Sarti 2003). 
Równolegle z postępująca globalizacją rozpoczęły się procesy regionalnej integracji gospodarczej, zainicjowane jeszcze pod koniec lat 80. XX w. przez nowe demokratyczne rządy Argentyny i Brazylii (Manzetti 1990).

Powstający Wspólny Rynek Południa (Mercado Commun del Sur - MERCOSUR) dodatkowo podnosił jeszcze atrakcyjność tworzących go państw w oczach międzynarodowych inwestorów. Z drugiej strony szeroki strumień bezpośrednich inwestycji zagranicznych kierowanych na rozbudowę przemysłu samochodowego skłaniał poszczególne kraje, a szczególnie Argentynę i Brazylię, do opóźniania liberalizacji w tym sektorze, stosowania polityki ulg podatkowych i zachęt inwestycyjnych dla przyciągnięcia jak największej liczby inwestycji na teren swojego kraju. Polityka ta stała w ostrej sprzeczności z wprowadzaną liberalizacją handlu w ramach MERCOSUR, powodowała także częste konflikty i napięcia polityczne, gdyż oba kraje traktowały swój przemysł samochodowy jako strategiczny sektor przyczyniający się do wzrostu innowacyjności i konkurencyjności całej gospodarki (Gomez Mera 2005; Amann i in. 2007; Gomez Mera 2007).

Celem opracowania jest prześledzenie wpływu procesów globalizacji oraz integracji regionalnej na brazylijski przemysł samochodowy, ukazanie zmian w polityce przemysłowej państwa względem tego sektora oraz ich wpływu na pozyskanie nowych inwestycji, a także prześledzenie specjalnej polityki integracyjnej w ramach MERCOSUR prowadzonej względem przemysłu samochodowego.

\section{REFORMY GOSPODARCZE I ROZWÓJ WSPÓŁPRACY W RAMACH MERCOSUR}

Wraz z wprowadzanymi przez demokratyczne rządy reformami gospodarczymi, mającymi doprowadzić do zahamowania wysokiej inflacji i wpłynąć na ożywienie gospodarcze po tzw. „straconej dekadzie” lat 80 . XX w., dwa rywalizujące ze sobą od lat państwa Ameryki Południowej, Argentyna i Brazylia, postanowiły także rozwijać i intensyfikować dwustronną współpracę gospodarczą w celu podniesienie ich atrakcyjności inwestycyjnej w oczach międzynarodowych korporacji. Współpraca ta przybrała bardziej zinstytucjonalizowaną formę wraz z podpisaniem w marcu 1991 r. porozumienia powołującego MERCOSUR. Poza Argentyną i Brazylią do ugrupowania przystąpiły także Paragwaj i Urugwaj (Manzetti 1990; Cason 2000).

Początkowa umowa ustalała terminarz, prowadzący do utworzenia od początku $1995 \mathrm{r}$. strefy wolnego handlu obejmującej większość towarów. Był to śmiały plan, zakładający bardzo szybką integrację, nie uwzględniał jednak wielu trudności i komplikacji. Głównym problemem, który się ujawnił w trakcie negocjacji, były rozbieżności w polityce makroekonomicznej między dwoma najważniejszymi krajami członkowskimi. Argentyna wprowadziła w kwietniu 1991 r. restrykcyjną politykę stabilizacyjną, natomiast Brazylia unikała jej aż do lipca 1994 r. Najpoważniejszą konsekwencją tych rozbieżności dla procesu integracji regionalnej było przewartościowanie argentyńskiego peso, prowadzące do zalania Argentyny przez brazylijski import. W konsekwencji zmusiło ją to do wprowadzenia w listopadzie 1992 r. tzw. podatku statystycznego na import w przedziale od 3\% do 10\%, który był w głównym stopniu wymierzony w brazylijski eksport. W celu skłonienia Argentyny do złagodzenia swojej protekcjonistycznej polityki Brazylia zgodziła się zredukować jej wysoki ujemny bilans handlowy poprzez zakup większej ilości argentyńskiej pszenicy i oleju. 
Przyczyniło się to do stopniowego wycofania podatku importowego, jednakże uzmysłowiło rządzącym, że droga prowadząca do swobodnej wymiany handlowej będzie trudniejsza niż zakładano (Cason 2000, s. 28).

Utworzenie MERCOSUR wpłynęło na ożywienie wymiany handlowej między państwami członkowskimi. W początkowym okresie dzięki odkładaniu przez Brazylię restrykcyjnej reformy stabilizującej gospodarkę i zwalczającej nawroty hiperinflacji osiągnęła ona wysoki dodatni bilansu wymiany handlowej. Dopiero zainicjowany w lipcu 1994 r. plan stabilizacyjny, zwany od wprowadzonej waluty Planem Reala, przyczynił się do zdławienia hiperinflacji, a sztywne powiązanie reala z dolarem podniosło jego wartość. Liberalizacja wymiany handlowej oraz realna aprecjacja reala, wpłynęły na gwałtowny wzrost importu i ujemny bilans wymiany handlowej z zagranica, a także w ramach MERCOSUR (ryc. 1 i 2).

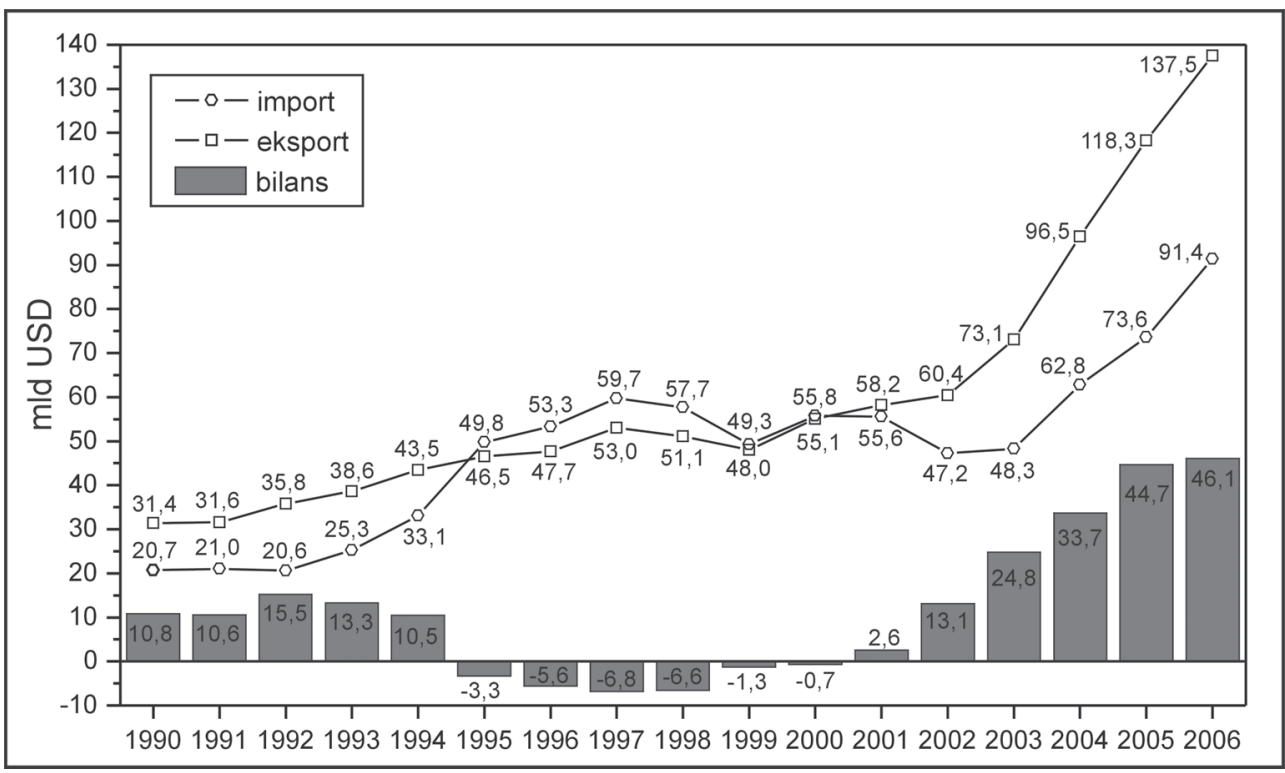

Ryc. 1. Zmiany wielkości handlu zagranicznego Brazylii w latach 1990-2006

Źródło: opracowanie własne na podstawie: MERCOSUR Report no. 6, 7, 11, różne lata

Od początku stycznia 1995 weszło w życie porozumienie powołujące wspólny rynek południa. Bezcłowy handel w obrębie MERCOSUR objął ok. 90\% towarów. Wprowadzono także wspólną zewnętrzną stawkę celną, wahającą się od $0 \%$ do $20 \%$ i obejmującą ok. 85\% importowanych towarów. Każde z państw miało możliwość przygotowania listy towarów uznawanych za „wrażliwe” na zagraniczną konkurencję, które miały być chronione wyższymi stawkami celnymi do 1999 r. - w przypadku Argentyny i Brazylii, a do 2001 r. w przypadku Paragwaju i Urugwaju. Jednym z najważniejszych sektorów, którego produkty nie zostały objęte wspólną stawką celną ani swobodną wymianą w ramach MERCOSUR, był przemysł motoryzacyjny (Cason 2000; Baer, Cavalcanti, Silva 2002). 
Zniesienie ograniczeń przyczyniło się do dalszego wzrostu wielkości wymiany handlowej Brazylii z zagranicą, a szczególnie z państwami MERCOSUR. Niekorzystny okazał się natomiast utrzymujący się w obu przypadkach ujemny bilans. Pogłębiało to napięcia gospodarcze i utrudniało utrzymanie płynności finansowej, a w końcu doprowadziło do wybuchu kryzysu walutowego w styczniu 1999 r. i deprecjacji reala o 66\% w ciagu miesiąca, z 1,2 do 2 reali za dolara (Żuławska, 2003). Kryzys ten doprowadził do zmniejszenie wymiany handlowej, a szczególnie ograniczenia importu, co miało na celu poprawę bilansu handlowego kraju. Jednocześnie zaobserwowano spadek eksportu, który w dużej mierze wynikał z ograniczeń celnych, jakie narzuciły na Brazylię kraje MERCOSUR, szczególnie Argentyna, obawiające się zalania przez brazylijskie towary, stające się coraz bardziej konkurencyjne w obliczu deprecjacji reala (ryc. 1 i 2 ).

W kolejnych latach gospodarka Brazylii i innych państw MERCOSUR znów weszła w trudny okres wywołany kryzysem argentyński w 2002 r. Spowodował on ponowne gwałtowne ograniczenie brazylijskiego eksportu do MERCOSUR, gdyż to Argentyna była jego głównym odbiorcą w ramach tego ugrupowania. Zła sytuacja w tym kraju odstraszyła także inwestorów zagranicznych z sąsiedniej Brazylii, przyczyniając się do odpływu kapitałów (ryc. 2).

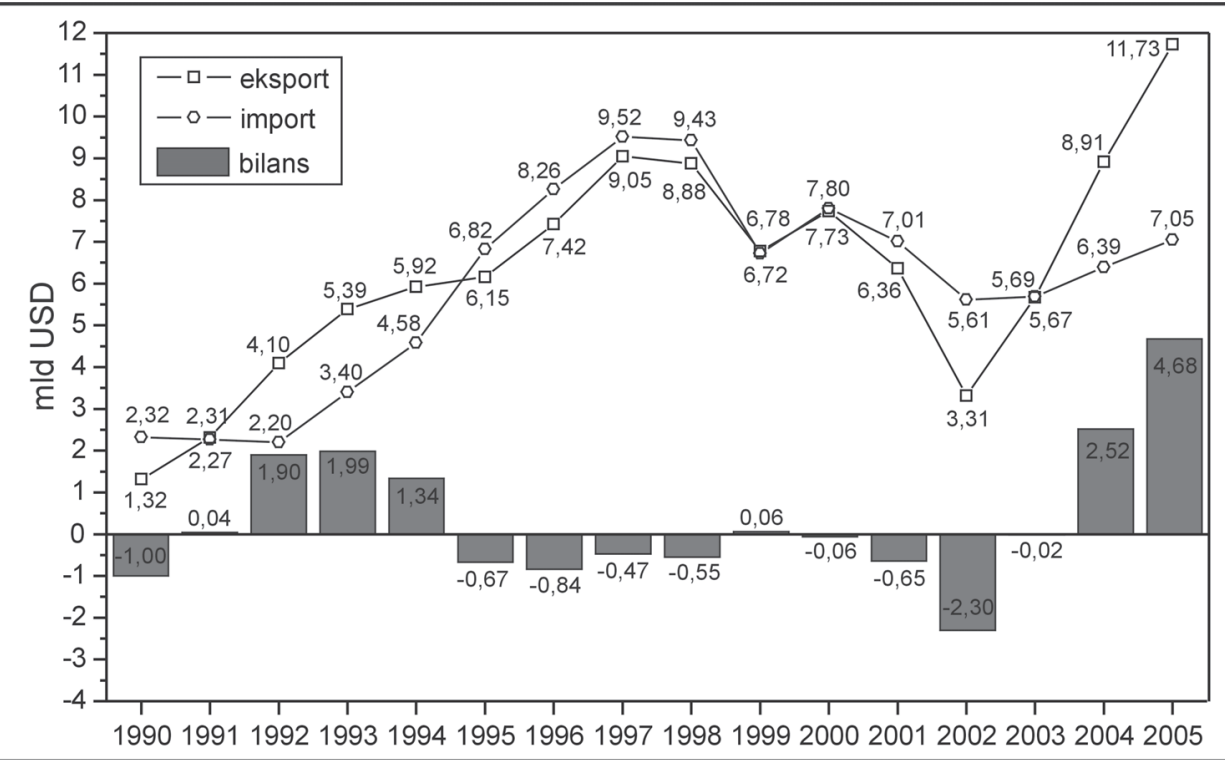

Ryc. 2. Wielkość wymiany handlowej Brazylii z państwami MERCOSUR w latach 1990-2005

Źródło: opracowanie własne na podstawie: MERCOSUR Report no. 6, 7, 11, różne lata 


\section{ZMIANY W BRAZYLIJSKIEJ POLITYCE W PRZEMYŚLE SAMOCHODOWYM}

Wraz z postępującą liberalizacją gospodarczą na początku lat 90. XX w. polityka brazylijska względem sektora motoryzacyjnego uległa radykalnej zmianie. Rząd prezydenta Fernanda Collor de Melo dostrzegał konieczność pomocy brazylijskiemu przemysłowi motoryzacyjnemu w dostosowaniu się do nowych warunków konkurencji międzynarodowej, jednakże poza wykluczeniem tego sektora z procesu integracji regionalnej stosował jedynie zwolnienia podatkowe i zachęty finansowe, jako instrumenty promocji zwiększania produkcji i przyciągania inwestycji. Decyzje były dyskutowane i wprowadzane w życie w ramach nowo powołanych sektorowych izb gospodarczych, które miały zapewnić porozumienie pomiędzy związkami zawodowymi, biznesem i przedstawicielami rządu (Cason 2000; Gomez Mera 2007).

Uzgodnienia izby gospodarczej przemysłu motoryzacyjnego, podpisane w latach 19921993, skutkowały znacznym zmniejszeniem krajowych stawek podatkowych, co zaowocowało znaczącym obniżeniem cen produkowanych pojazdów i przyczyniło się do odwrócenia spadkowego trendu w produkcji samochodów. Ogólna wielkość produkcji samochodów wzrosła z 914,6 tys. sztuk w 1990 r. do 1391,4 tys. sztuk w 1993 r. (Gomez Mera 2007).

W okresie rządów prezydenta Itamara Franco, który zajął miejsce odwołanego w 1992 r. w drodze impeachmentu F. Collor de Melo, zwiększył się bezpośredni nacisk firm samochodowych na rząd w celu uzyskania dalszych przywilejów i ulg podatkowych. Nowy prezydent okazał się być bardzo podatny na naciski silnego lobby zrzeszającego krajowych producentów samochodów, co doprowadziło do rozpoczęcia negocjacji w sprawie dalszych redukcji podatków od produkcji małych samochodów. Wstępne umowy podpisane z poszczególnymi firmami zastąpiono w 1993 r. wprowadzeniem tzw. porozumienia Tani Samochód (Carro Popular regime). Promował on, poprzez bodźce podatkowe, produkcję małych samochodów (pojemność silnika do $1000 \mathrm{~cm}^{3}$ ) dostępnych dla szerszego grona średnio zamożnych klientów. Program ten okazał się bardzo skuteczny pod względem zwiększenia krajowej produkcji oraz popytu na tego typu pojazdy, jednakże równocześnie nieefektywny w przyciaganiu nowych inwestycji zagranicznych w tym sektorze. Przeciwieństwem tego był program rozwoju przemysłu samochodowego wprowadzony w 1991 r. w Argentynie, oferujący szeroki wachlarz zachęt i przywilejów dla firm otwierających działalność w tym kraju. Ta silnie interwencjonistyczna polityka miała na celu rozwój sektora motoryzacyjnego oraz wzrost eksportu. Zwiększenie wpływów eksportowych oraz napływ inwestycji zagranicznych odgrywały także kluczową rolę w realizowanej przez ministerstwo finansów strategii stabilizacji poprzez związanie argentyńskiego peso z dolarem (tzw. Plan Wymienialności) (Gomez Mera 2007; Żuławska 2003).

Ta asymetria w polityce gospodarczej względem przemysłu motoryzacyjnego prowadzona przez dwóch głównych członków MERCOSUR była kluczowym czynnikiem przyjęcia przez Brazylię w czerwcu 1995 r. tzw. Porozumienia Samochodowego (Regime Automotivo), nawiązującego do programu wdrożonego w Argentynie. Jego głównym celem była promocja produkcji samochodów w Brazylii, do czego miały zachęcać subsydia dla producentów i bariery taryfowe ograniczające import. Program ten składał się z trzech głównych elementów: zachęt inwestycyjnych, mierników promocji eksportu oraz ilościowych ograniczeń importu (Gomez Mera 2007; Cason 2000). Miał też ograniczyć wartość importu samochodów, któ- 
ra zaczęła gwałtownie wzrastać w 1995 r., co wpływało na pogłębianie deficytu wymiany handlowej i stanowiło wielkie zagrożenie dla wprowadzanego od 1 lipca 1994 r. Planu Reala (ryc. 3).

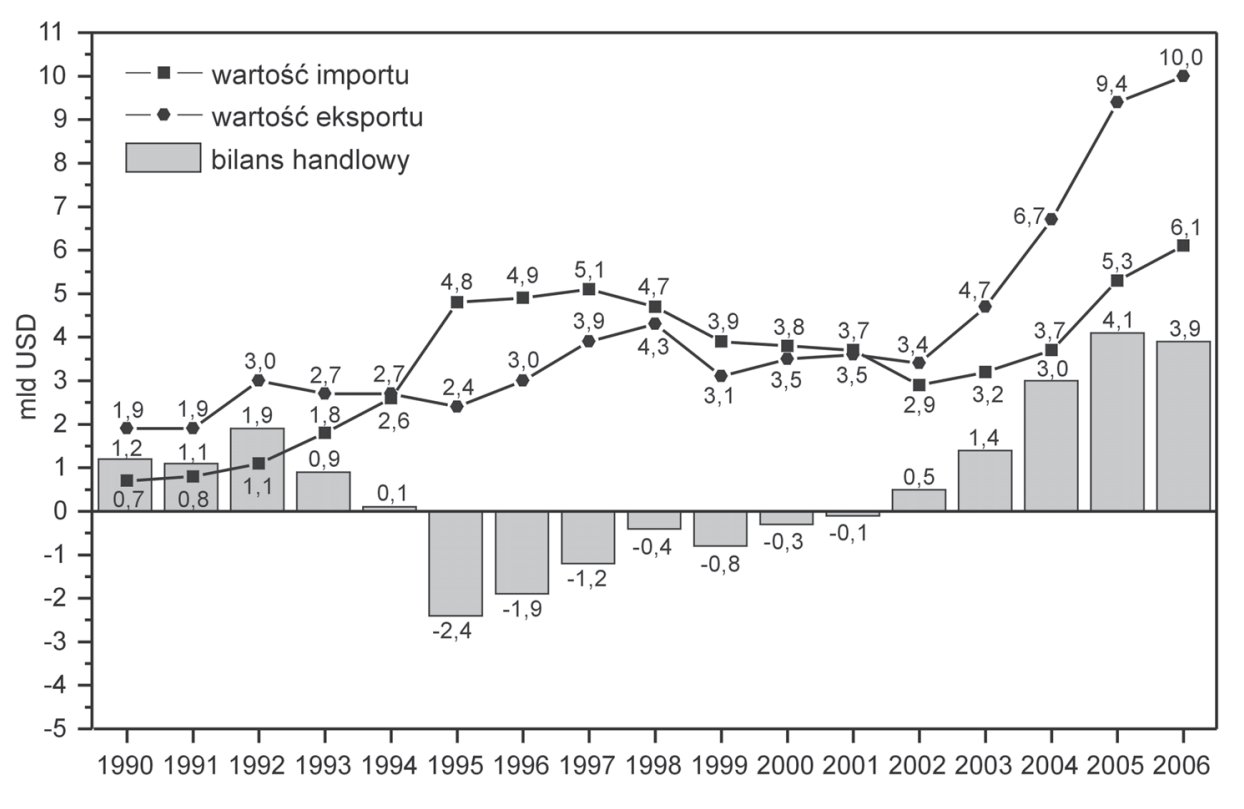

Ryc. 3. Zmiany bilansu handlowego przemysłu samochodowego Brazylii w latach 1990-2006

Źródło: opracowanie własne na podstawie Anuário da Indústria Automobilistica Brasileira, 2007

Dodatkowym zagrożeniem dla brazylijskiej gospodarki był kryzys meksykański, który w grudniu 1994 r. zmusił rząd tego kraju do dewaluacji waluty. Obawa przed jego rozprzestrzenieniem się na inne państwa regionu, tzw. efekt tequili, skłoniła inwestorów do wycofywania kapitałów, co poważnie zagrażało utrzymaniu płynności finansowej przez Brazylię. Dlatego też uważana za skrajnie liberalną administracja prezydenta F. Cardoso zdecydowała się na wprowadzenie tak protekcjonistycznego programu, który z jednej strony ograniczałby wartość importu samochodów, w sytuacji trochę przewartościowanej waluty, a z drugiej zachęcał do napływu kapitał zagraniczny (Żuławska 2003; Gomez Mera 2005; Gomez Mera 2007).

Jednostronne wprowadzenie tak restrykcyjnego programu, ograniczającego import samochodów, spotkało się z dużym sprzeciwem strony argentyńskiej, gdyż najsilniej uderzało to w funkcjonujący w tym kraju przemysł samochodowy, dla którego Brazylia była jednym z najważniejszych rynków zbytu. Działania rządu brazylijskiego zachwiały współpracą w ramach MERCOSUR i w obliczu ostrego sprzeciwu państw członkowskich zmusiły Brazylię do podjęcia negocjacji, zmierzających do wypracowania stanowiska możliwego do zaakceptowania, szczególnie przez Argentynę. Już w styczniu 1996 r. oba kraje ogłosiły osiągnięcie porozumienia w sektorze samochodowym, ustanawiającego reguły wymiany handlowej, które miały obowiązywać do roku 2000. Uzgodniono, że w przypadku Brazylii 
eksporterzy samochodów będą mogli importować tylko tyle, ile wyeksportowali, płacąc połowę cła, które wynosiło $70 \%$ na gotowe pojazdy. Ponadto w celu wzmocnienia lokalnego przemysłu części samochodowych i uniknięcia inwestycji nastawionych tylko na budowę fabryk montażowych, bezcłowy handel samochodami w obrębie MERCOSUR wymagał, aby co najmniej 50\% jego części było wykonane w kraju, z którego pochodził (Cason 2000, s. 31-32; O’Keefe, Haar 2001, s. 17-18).

Pod koniec 1998 r. uzgodniono kolejne porozumienie ustanawiające czteroletni okres przejściowy w przemyśle motoryzacyjnym, trwający od 2000 do 2004, kiedy to miał zostać wprowadzony całkowicie wolny handel jego wyrobami w obrębie MERCOSUR. W okresie przejściowym wspólna zewnętrzna taryfa celna na gotowe samochody miała wynosić 35\%, natomiast na części samochodowe wahała się od $14 \%$ do $18 \%$. Podniesiono również wymóg udziału krajowych części do $60 \%$ wartości pojazdu, jeśli miał on być uznany za krajowy, a co za tym idzie objęty bezcłową wymianą w obrębie MERCOSUR (Cason 2000, s. 32; O'Keefe, Haar 2001, s. 18-20).

Następne lata pokazały, że pełna liberalizacja handlu w obrębie MERCOSUR obejmująca przemysł motoryzacyjny nie jest jeszcze możliwa do osiągnięcia, a każde z państw członkowskich traktuje ten sektor jako czynnik rozwoju krajowej gospodarki. Dlatego też nie udało się wprowadzić od 2004 r. strefy wolnego handlu na wyroby przemysłu samochodowego, odsuwając termin do stycznia 2006 r., a następnie do 2008 r. Za każdym razem ustalano jednocześnie sposób pomiaru i współczynniki pozwalające obliczyć wartość bezcłowego eksportu danego państwa, która bezpośrednio wynikała z wartości jego importu (MERCOSUR Report no. 11, 2006, s. 48-51).

\section{NAPŁYW INWESTYCJI ZAGRANICZNYCH \\ DO BRAZYLIJSKIEGO PRZEMYSŁU SAMOCHODOWEGO}

Od początku lat 90. jednym z zasadniczych celów brazylijskiej polityki przemysłowej było pozyskanie zagranicznych kapitałów potrzebnych do modernizacji istniejących, jak i rozwoju nowych zakładów przemysłowych. W przypadku przemysłu samochodowego zdecydowanie trudniej było pozyskać fundusze na jego modernizację i rozwój na drodze prywatyzacji, gdyż praktycznie w całości znajdował się on w rękach dużych koncernów międzynarodowych, jedynie w przemyśle podzespołów i części samochodowych działały liczne firmy z rodzimym kapitałem. W celu przyciągnięcia inwestycji do tego sektora Brazylia musiała pokazać międzynarodowym firmom, że jest potencjalnym chłonnym i stabilnym rynkiem zbytu, dlatego tak ważną rolę odgrywał rozwój współpracy w ramach MERCOSUR, jak i stabilizacja własnej gospodarki, a przede wszystkim ograniczenie inflacji i podniesienie siły nabywczej ludności.

Poszerzanie rynku zbytu o państwa członkowskie MERCOSUR, a szczególnie Argentynę, postępowało bardzo opornie, ponieważ, podobnie jak Brazylia, starała się ona pozyskać jak najwięcej wartości inwestycji zagranicznych dla swojego przemysłu motoryzacyjnego, blokując pełną liberalizację wymiany handlowej w tym sektorze, co przeanalizowano powyżej. Z drugiej zaś strony do momentu wprowadzenia Planu Reala w połowie 1994 r., Brazylia borykała się z problemem hiperinflacji, co ograniczało chłonność rynku wewnętrznego, gdyż podrażało koszty bądź całkowicie uniemożliwiało zaciągnięcie kredytu w większości przypadków niezbędnego do zakupu nowego pojazdu. Dlatego też w pierwszej połowie lat 90 . to 
Argentyna, wprowadzająca już od 1991 r. program stabilizacyjny, stała się atrakcyjniejszym miejscem do lokalizacji inwestycji sektora motoryzacyjnego, natomiast do Brazylii napływał zdecydowanie mniejszy strumień BIZ, związany głównie z modernizacją i rozbudową istniejących fabryk (ryc. 4).

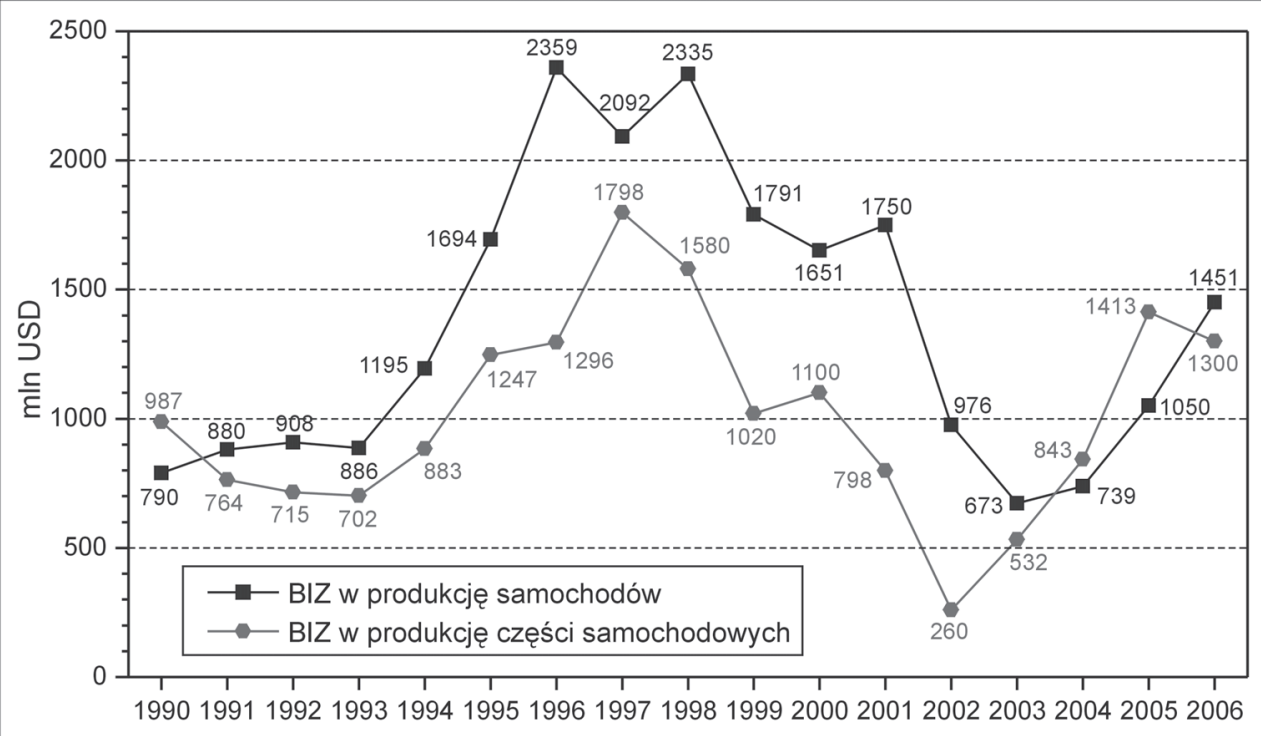

Ryc. 4. Zmiany wielkości napływu Bezpośrednich Inwestycji Zagranicznych (BIZ) do brazylijskiego przemysłu samochodowego w latach 1990-2006

Źródło: opracowanie własne na podstawie Anuário da Indústria Automobilistica Brasileira, 2007; Brazilian Autoparts Industry Performance, 2007

Sytuacja zaczęła się zmieniać od wprowadzenia w 1994 r. programu stabilizacyjnego ograniczającego inflację, który był zarazem jasnym sygnałem dla zagranicznych inwestorów, że rząd Brazylii zamierza przeprowadzić bolesne, ale niezbędne reformy stabilizujące gospodarkę i finanse państwa. Ponadto wprowadzone na krótko w połowie 1995 r. Porozumienie Samochodowe było kolejnym wyraźnym sygnałem dla zagranicznych inwestorów, że Brazylia nie zamierza zrezygnować z protekcjonistycznej polityki względem sektora motoryzacyjnego. Działania władz umocniły przekonanie wśród kierownictwa koncernów samochodowych, że tylko poprzez bezpośrednie inwestycje w Brazylii uzyskają one pełny dostęp do tego rynku. Wynikiem tego było ograniczanie, w drugiej połowie lat 90., napływu inwestycji do Argentyny, a w niektórych przypadkach (np. Fiat, Renault) przeniesienie większości działalności produkcyjnej do Brazylii. Dodatkową zachętą dla napływu nowych inwestycji w tym sektorze były także wysokie ulgi podatkowe i pomoc finansowa ze strony brazylijskich stanów i miast, rywalizujących o przyciagnięcie inwestorów (Amann i in. 2007; Rodriguez-Poze, Arbix 2001).

W efekcie splotu wymienionych czynników w drugiej połowie lat 90. XX w. doszło do gwałtownego napływu BIZ. W latach 1995-2001 do brazylijskiego przemysłu samochodowego napłynęło ponad 13,67 mld USD, co stanowiło 58,9\% z ogólnej wielkości 23,22 mld USD inwestycji, jakie napłynęły do tego sektora w latach 1990-2006. Napływ 
BIZ do przemysłu podzespołów i części samochodowych był również zwiększony w latach 1995-2001, kiedy to zainwestowano ok. 8,8 mld USD, czyli 51,0\% z 17,24 mld USD zainwestowanych w ten sektor w latach 1990-2006 (ryc. 4).

Wraz z napływem inwestycji zagranicznych i budową nowych zakładów gwałtownie wzrosła potencjalna moc produkcyjna brazylijskiego przemysłu samochodowego, osiagając z końcem 2003 r. poziom ok. 3,3 mln sztuk (tab. 1). Biorąc pod uwagę fakt, że w 2004 r. wielkość produkcji wyniosła niewiele ponad 2,3 mln sztuk, można stwierdzić, iż zainstalowane moce produkcyjne były wykorzystane jedynie w 70,3\%. Zwiększenie produkcji do ponad 2,6 mln sztuk w 2006 r. sprawiło, że wykorzystanie mocy produkcyjnych wzrosło do 79,2\%, jednakże nadal w sektorze tym pozostają spore rezerwy. Warto zaznaczyć, iż nawet przy poziomie produkcji z 2006 r. brazylijski rynek motoryzacyjny nie jest w stanie wchłonąć jej w całości, gdyż według danych za ten rok Brazylijczycy zakupili jedynie 1927,7 tys. nowych samochodów, z czego 1785,9 tys. stanowiły samochody krajowej produkcji (Anuário da Indústria Automobilística Brasileira, 2007).

Tab. 1. Zainstalowana moc produkcyjna w brazylijskich filiach międzynarodowych koncernów samochodowych w 2003 r.

\begin{tabular}{|c|c|c|}
\hline Nazwa firmy & $\begin{array}{l}\text { Lokalizacja fabryki } \\
\text { (miasto, stan) }\end{array}$ & $\begin{array}{l}\text { Moc produkcyjna } \\
\text { (w sztukach) }\end{array}$ \\
\hline \multirow{3}{*}{ General Motors (GM) } & Săo Caetano do Sul, Săo Paulo & 180000 \\
\hline & Săo Jose dos Campos, Săo Paulo & 350000 \\
\hline & Gravatai, Rio Grande do Sul & 200000 \\
\hline \multirow{2}{*}{ Ford } & Săo Bernardo do Campo, Săo Paulo & 200000 \\
\hline & Camaçari, Bahia & 250000 \\
\hline \multirow{4}{*}{ Volkswagen } & Săo Bernardo do Campo, Săo Paulo & 524000 \\
\hline & Taubate, Săo Paulo & 305000 \\
\hline & Resende, Rio de Janeiro & 30000 \\
\hline & Săo Jose dos Pinhais, Parana & 160000 \\
\hline Renault-Nissan & Săo Jose dos Pinhais, Parana & 120000 \\
\hline \multirow{2}{*}{ Fiat } & Betim, Minas Gerais & 610000 \\
\hline & Sete Lagoas, Minas Gerais & 62000 \\
\hline \multirow{3}{*}{ Daimler-Chrysler } & Săo Bernardo do Campo, Săo Paulo & 60000 \\
\hline & Campo Largo, Parana & 12000 \\
\hline & Juiz do Fora, Minas Gerais & 70000 \\
\hline Peugeot-Citröen & Porto Real, Rio de Janeiro & 100000 \\
\hline Volvo & Kurytyba, Parana & - \\
\hline Honda & Sumare, Săo Paulo & 45000 \\
\hline Toyota & Indaiatuba, Săo Paulo & 15000 \\
\hline Mitsubishi & Catalăo, Săo Paulo & 3000 \\
\hline Ogółem & & 3296000 \\
\hline
\end{tabular}


Brazylijski przemysł samochodowy zmuszony jest więc nadal do poszukiwania zagranicznych rynków zbytu na swoje wyroby dla utrzymania opłacalnego poziomu wykorzystania zainstalowanych mocy produkcyjnych. $Z$ tego względu tak ważne znaczenie ma dla niego liberalizacja wymiany handlowej i zacieśnianie współpracy w ramach MERCOSUR, a także z innymi państwami Ameryki Łacińskiej i świata. Z drugiej zaś strony rząd nadal stara się chronić krajowych producentów, traktując ten sektor przemysłu priorytetowo, gdyż uznaje go za nośnik nowych technologii i innowacji, które przenikają do gospodarki. Dużą rolę w wywieraniu nacisków, hamujących proces liberalizacji wymiany handlowej w tym sektorze odgrywa także silne lobby zrzeszające brazylijskie firmy przemysłu samochodowego skupione w Krajowym Stowarzyszeniu Producentów Pojazdów Samochodowych (Associaçăo Nacional dos Fabricantes de Veiculos Automotores - ANFAVEA) oraz Krajowym Związku Przemysłu Części dla Pojazdów Samochodowych (Sindicato Nacional da Indústria de Componentes para Veículos Automotores - SINDIPEÇAS).

\section{BRAZYLIJSKI HANDEL ZAGRANICZNY SAMOCHODAMI}

Od momentu liberalizacji wymiany handlowej z zagranicą na początku lat 90 . XX w. obserwuje się postępujący wzrost importu samochodów do Brazylii. Maksymalny poziom blisko 370 tys. sztuk osiągnął on w 1995 r. Warto jednak zauważyć, że w tym okresie udział samochodów importowanych z Argentyny był raczej niski, gdyż dominowały w nim głównie nowsze i lepiej wyposażone modele sprowadzane z Europy i Ameryki Północnej. Od 1996 r sytuacja uległa zmianie i Argentyna staje się stopniowo największym zagranicznym dostawcą samochodów na brazylijski rynek, przy jednoczesnej tendencji do ograniczania wielkości importu. Wynikało to w dużej mierze z prowadzonej polityki gospodarczej w ramach MERCOSUR, w ramach której od 1995 r. ograniczono import samochodów spoza ugrupowania, natomiast promowano wymianę między państwami członkowskimi. Nawet w latach kryzysu gospodarczego w Argentynie (2002-2003) sprowadzane z niej samochody stanowiły ponad połowę brazylijskiego importu (ryc. 5).

Szczególnie ważne dla brazylijskiego przemysłu samochodowego było zdobycie nowych rynków zbytu, co wynikało z ograniczonej chłonności rynku krajowego. W tym celu rząd starał się prowadzić aktywną politykę promującą eksport, jak również zabiegał o liberalizację handlu z państwami, które mogły się stać potencjalnymi odbiorcami brazylijskich samochodów. W początkowym okresie głównym odbiorcą brazylijskiego eksportu była Argentyna, o czym świadczy wzrost jej udziału w całkowitym eksporcie samochodów latach 1990-1997 z 19,9\% do 67,2\% (ryc. 6).

Wraz z pogarszaniem się sytuacji gospodarczej w regionie, a szczególnie w okresie kryzysu finansowego w Argentynie, udział tego kraju w brazylijskim eksporcie samochodów spadł do 14,9\% w 2002 r. Poprawa sytuacji gospodarczej w kolejnych latach sprawiła, że Argentyna ponownie odzyskała dominującą pozycję i w 2006 r. jej udział w eksporcie samochodów wzrósł do 32,7\% (ryc. 6 i 7).

Załamanie się eksportu do Argentyny na początku XXI w. zbiegło się w czasie z uruchamianiem nowych fabryk samochodów wybudowanych w drugiej połowie lat 90 . XX w. Zmusiło to działające w Brazylii koncerny do szukania alternatywnych rynków zbytu. $\mathrm{Na}$ szczęście, dzięki nowym inwestycjom brazylijski przemysł samochodowy stał się bardziej 


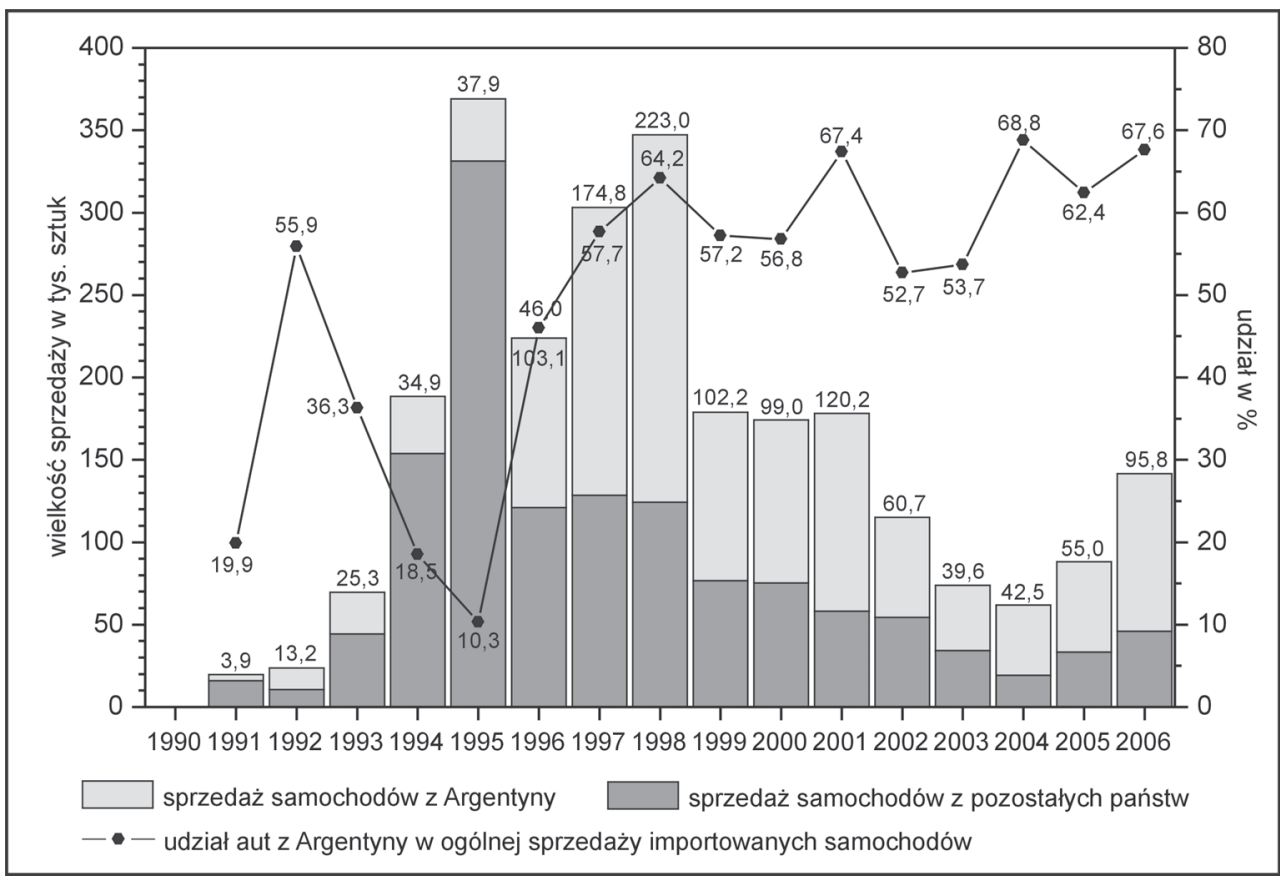

Ryc. 5. Udział Argentyny w brazylijskim imporcie samochodów w latach 1990-2006

Źródło: opracowanie własne na podstawie: Anuário da Indústria Automobilística Brasileira, 2007

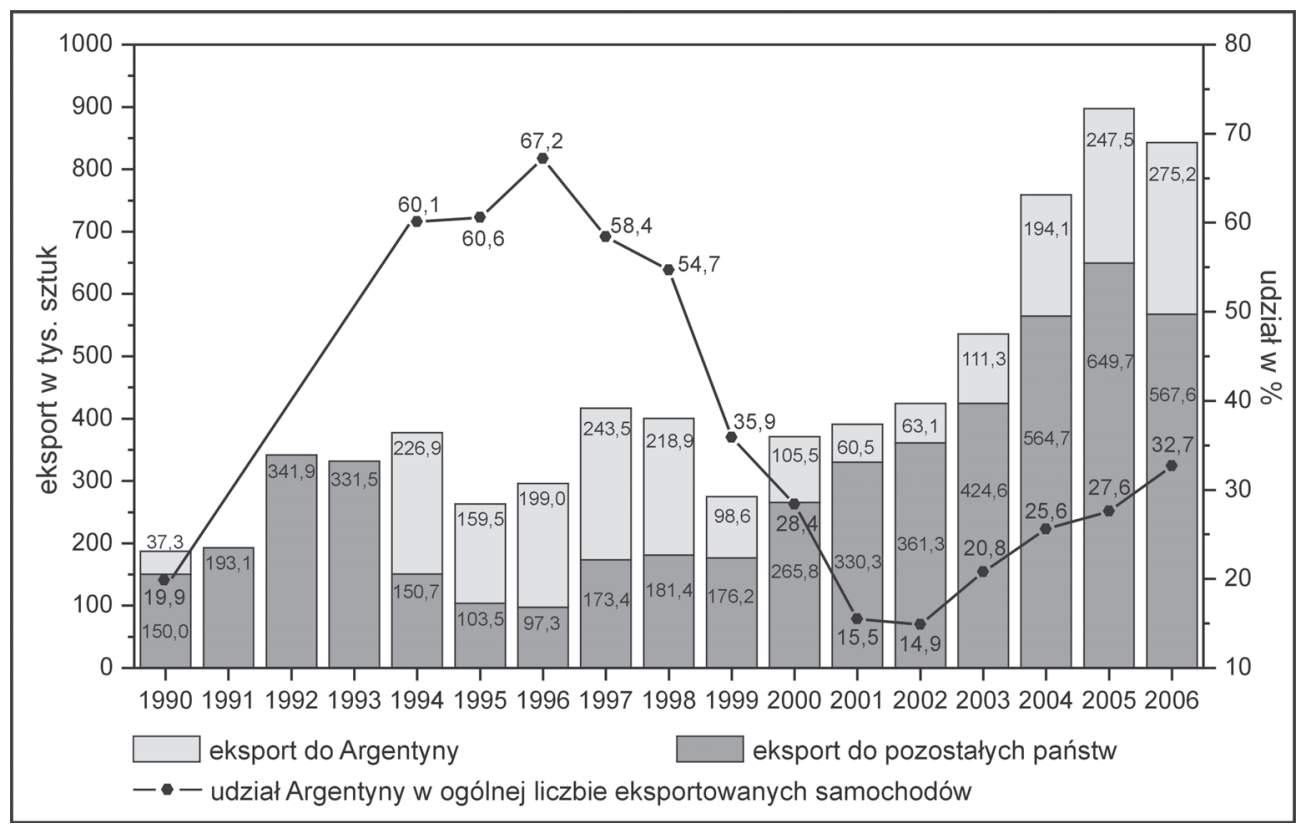

Ryc. 6. Udział Argentyny w brazylijskim eksporcie samochodów w latach 1990-2006

Źródło: opracowanie własne na podstawie Anuário da Indústria Automobilistica Brasileira, 2007 
konkurencyjny w skali światowej, a jego wyroby znajdowały nabywców nawet na rynku państw wysoko rozwiniętych. Dzięki temu wielkość brazylijskiego eksportu w latach 2000 2006 wzrosła o $227 \%$ z 371,3 tys. do 842,8 tys. sztuk (ryc. 6).

Głównymi odbiorcami brazylijskich samochodów są kraje rozwijające się, szczególnie z Ameryki Łacińskiej. Poza analizowaną powyżej Argentyną, drugim pod względem wielkości zagranicznym rynkiem zbytu pozostaje Meksyk, do którego w latach 2000-2006 trafiało od ok. 1/5 do 1/4 ogółu eksportowanych pojazdów. Natomiast w ciągu ostatnich trzech lat coraz większą rolę zaczął także ogrywać eksport do RPA i Chin (ryc. 7).

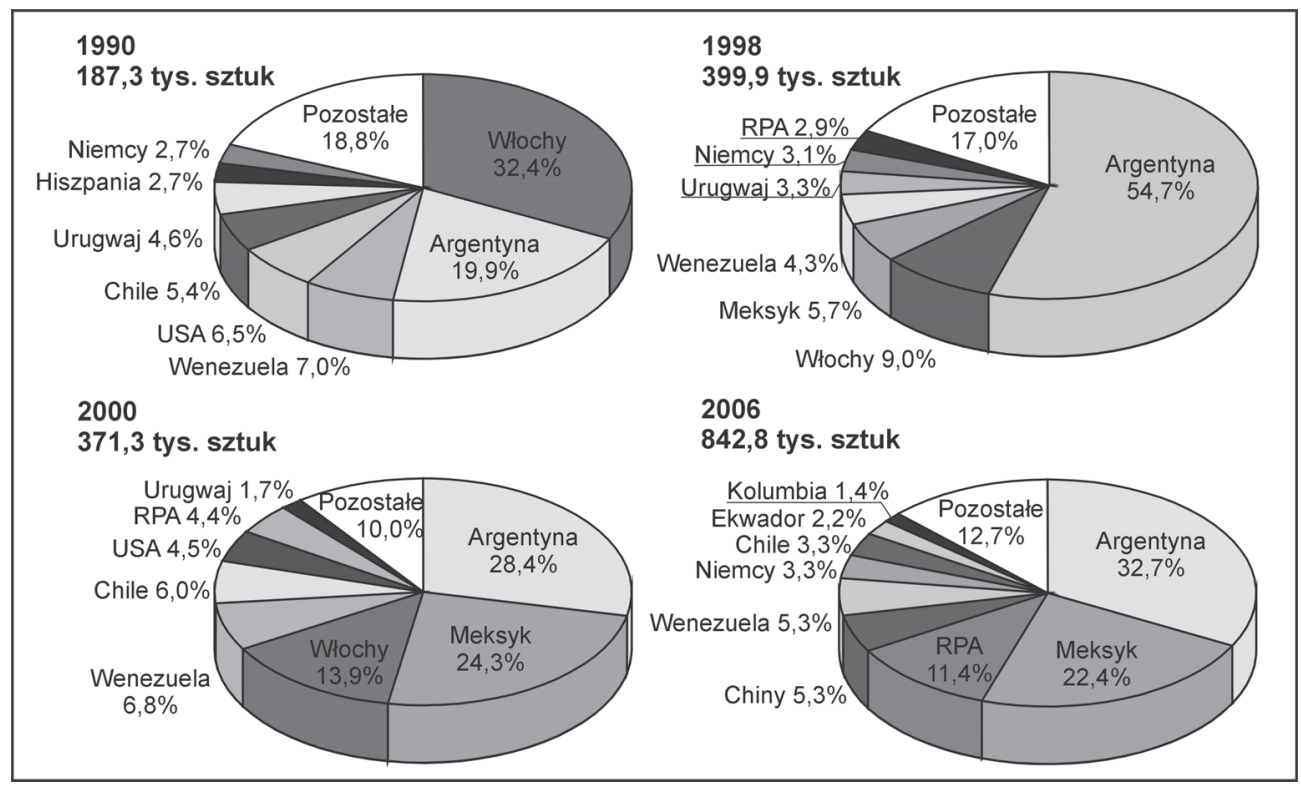

Ryc. 7. Główni odbiorcy brazylijskiego eksportu samochodów w wybranych latach

Źródło: opracowanie własne na podstawie Anuário da Indústria Automobilística Brasileira, 2007

\section{Podsumowanie}

Zmiany w brazylijskim przemyśle samochodowym w latach 1990-2006 są w dużej mierze konsekwencją wywołanych procesem globalizacji przekształceń w tej branży. Przyczyniły się one do modernizacji istniejących zakładów oraz unowocześnienia i zwiększenia efektywności produkcji (Tigre i in. 1999), a także doprowadziły do pojawienia się na brazylijskim rynku nowych inwestycji lokowanych przez istniejące filie międzynarodowych koncernów samochodowych oraz przez zupełnie nowe firmy dążące do globalnej ekspansji, szczególnie na tzw. wschodzących rynkach. Do nowych koncernów, które pojawiły się w Brazylii w drugiej połowie lat 90. XX w., należą: Renault/Nissan, Peugeot/Citröen, Honda i Mitsubishi.

Czynnikiem przyciągającym nowe inwestycje motoryzacyjne była nie tylko poprawa sytuacji gospodarczej w Brazylii i rozwój współpracy w ramach MERCOSUR. Postępująca 
latach 90. XX w. integracja gospodarcza nie przebiegała bez napięć, konfliktów i kryzysów, powstających głownie między dwoma najważniejszymi państwami w tym ugrupowaniu - Argentyną i Brazylią. Mimo pojawiających się trudności udało się jednak utrzymać i kontynuować proces integracji, choć sektor motoryzacyjny pozostaje nadal objęty specjalną polityką odraczającą na razie swobodny handel jego wyrobami w ramach tego ugrupowania. Niemniej jednak sukcesy, jakie odnoszą państwa tworzące MERCOSUR na polu zacieśniania wzajemnej współpracy gospodarczej, są czytelnym sygnałem dla koncernów międzynarodowych do wkroczenia na ten rodzący się najludniejszy i najbardziej zamożny wspólny rynek w Ameryce Południowej.

Opisane powyżej uwarunkowania globalne i regionalne, a także odpowiednia polityka gospodarcza państwa sprawiły, że Brazylia utrzymała pozycję lidera w przemyśle samochodowym w skali całej Ameryce Łacińskiej. Udało się jej zmodernizować istniejący potencjał produkcyjny, a przy tym pozyskać największą część inwestycji zagranicznych koncernów samochodowych kierowanych do państw tego regionu. Dzięki integracji gospodarczej w obrębie MERCOSUR brazylijski przemysł samochodowy uzyskał większy i łatwiejszy dostęp do rynków tworzących go państw, szczególnie zaś chłonnego rynku argentyńskiego. Miało to duże znaczenie zwłaszcza w drugiej połowie lat 90 . XX w., kiedy to sektor ten był w fazie modernizacji i rozbudowy. Zapotrzebowanie na jego wyroby na rynku krajowym było zbyt niskie, a eksport na inne rynki napotykał na trudności i ograniczenia, wynikające albo z protekcyjnej polityki, albo z wysokiej konkurencji na rynkach państw rozwiniętych. To właśnie w tym okresie ponad połowa rosnącego brazylijskiego eksportu samochodów trafiała do Argentyny, co ułatwiło pozyskanie środków na modernizację i rozbudowę tego sektora w Brazylii. Późniejszy sukces eksportowy brazylijskiego przemysłu samochodowego w latach 2000-2006, polegający na ponaddwukrotnym zwiększeniu jego wielkości oraz opanowaniu nowych chłonnych rynków zbytu, nie byłby możliwy bez modernizacji i rozbudowy dokonanej w drugiej połowie lat 90., w której pośrednio pomogła Argentyna, umożliwiając szerszy dostęp do swojego rynku.

\section{Literatura}

Amann E., Haddad E., Perobelli F., Guilhoto J., 2007, Structural Change in the Brazilian Automotive Industry and Its Regional Impact, „Latin American Business Review”, vol. 7, no. 3-4, s. 97-119

Anuário da Indústria Automobilística Brasileira ediçăo 2007, 2007, Associaçăo Nacional dos Fabricantes de Veiculos Automotores - ANFAVEA, Săo Paulo (http://www.anfavea.com.br/anuario.html)

Baer W., Cavalcanti T., Silva P., 2002, Economic integration without policy coordination: the case of Mercosur, „Emerging Markets Review”, vol. 3, s. 269-219

Brazilian Autoparts Industry Performance 2007, 2007, SINDIPEÇAS, ABIPEÇAS, Săo Paulo. (http:// www.sindipecas.org.br)

Cason J., 2000, On the Road to Southern Cone Economic Integration, „Journal of Interamerican Studies and World Affairs", vol. 42/2, s. 23-42

Foreign Investment in Latin America and the Caribbean 1998, 1999, United Nations Economic Commission for Latin America and the Caribbean (ECLAC), Santiago de Chile

Foreign Investment in Latin America and the Caribbean 2003, 2004, United Nations Economic Commission for Latin America and the Caribbean (ECLAC), Santiago de Chile

Gomez Mera L., 2005, Explaining Mercosur's Survival: Strategic Sources of Argentine-Brazilian Convergence, ,Journal of Latin American Studies”, no. 37, s. 109-140 
Gomez Mera L., 2007, Macroeconomic Concerns and Intrastate Bargains: Explaining Illiberal Policies in Brazil's Automobile Sector, „Latin American Politics and Society”, vol. 49, no. 1, s. 113-140

Humphrey J., 2003, Globalization and supply chain networks: the auto industry in Brazil and India, „Global Networks”, vol. 3, no. 2, s. 121-141

Laplane M., Sarti F., 2000, Profit strategies in MERCOSUR: adaptability to changing conditions as a key factor for competition in unstable markets, „Actes du GERPISA”, no. 29, s. 10-20

Laplane M., Sarti F., 2003, Profit Strategies and National Growth Model in Developing Countries: the case of MERCOSUR, 11-th GERPISA International Colloquium, Paris

Manzetti L., 1990, Argentine-Brazilian Economic Integration: An Early Appraisal, „Latin American Research Review", vol. 25, no. 3, s. 109-140

MERCOSUR Report no. 6 1999-2000, 2000, Inter-American Development Bank, Integration and Regional Programs Department, Institute for the Integration of Latin America and the Caribbean (INTAL), Buenos Aires

MERCOSUR Report no. 7 2000-2001, 2001, Inter-American Development Bank, Integration and Regional Programs Department, Institute for the Integration of Latin America and the Caribbean (INTAL), Buenos Aires

MERCOSUR Report no. 11 2005-2006, 2006, Inter-American Development Bank, Integration and Regional Programs Department, Institute for the Integration of Latin America and the Caribbean (INTAL), Buenos Aires

O'Keefe T.A., Haar J., 2001, The Impact of MERCOSUR on the Automobile Industry, The North-South Agenda, Paper 50, North-South Center University of Miami

Rodriguez-Poze A., Arbix G., 2001, Strategies of waste: bidding wars in the Brazilian automobile sector, „International Journal of Urban and Regional Research”, vol. 25/1, s. 134-154

Queiroz S., Carvalho R.Q., 1999, Recent developments in Brazilian autovehicle and components trade: building the space of production in MERCOSUL, „Actes du GERPISA”, no. 25, s. 65-75

Tigre B.P., Laplane M., Lugones G., Porta F., 1999, Technological change and Modernization in the MERCOSUR Automotive Industry, „Integration and Trade”, no. 7-8, s. 123-145, Institute for the Integration of Latin America and the Caribbean (INTAL), Buenos Aires

Żuławska U., 2003, System gospodarczy Ameryki Łacińskiej, WGiSR, UW, Warszawa

\section{Impact of globalization and regional integration within MERCOSUR on the transformation of the Brazilian automobile industry in the years 1990-2006}

The aim of this paper is determining the influence of the globalization and regional integration processes on the Brazilian automobile industry. The paper also contains the analysis of changes in the state's industrial policy towards this sector and their influence on winning new foreign investments. The analysis also concerns changes in the MERCOSUR integration policy towards the automobile industry.

It was observed that the changes that occurred in the Brazilian automobile industry in the years 1990-2006 are to a large extent a consequence of world-wide transformations in the sector, caused by globalization. On one hand, the changes consisted in modernizing the existing plants, and on the other hand - in emergence of completely new enterprises that aimed at global expansion on the so-called rising markets. This led to the increase in production, diversification of the assortment of available models, and the increase in competition on the Brazilian market.

As for integration policy, the member states tried to postpone as long as possible complete liberalization of products trade in this industry within MERCOSUR. Owing to this, they were able to conduct individual policies in this sector, on one hand trying to maintain the barriers that protected 
their domestic markets, and on the other hand, trying to offer as much as possible to attract foreign investors. This led to numerous conflicts and great tension, chiefly between Argentina and Brazil, which endangered the process of economic integration. Still, the emerging problems were successfully overcome and the barriers for automobile industry trade within MERCOSUR were gradually eliminated. It was reflected in the rapid increase in car trade between the two countries in years 2003-2006. 